\title{
STATISTICAL REASONING TENTANG KEBIJAKAN SATU ANAK PER KELUARAG DI NEGERI TIRAI BAMBU ( CINA)
}

\author{
Toto Hermawan, Nuria Mahdra Fajarini, Nurni Utami \\ Program Studi Pendidikan Matematika \\ UCY
}

\begin{abstract}
Abstrak
Penelitian ini mencoba untuk menjelaskan tentang Distribusi peluang apa yang sesuai dengan pertumbuhan penduduk jika suatu keluarga harus mendapatkan anak laki-laki dan mengevaluasi kebijakan berdasarkan data yang diperoleh. Distribusi peluang yang sesuai dengan pertumbuhan penduduk jika suatu keluarga harus mendapatkan anak laki-laki adalah distribusi geometri. Untuk n keluarga digunakan distribusi binomial yang mengukur tingkat keberhasilan pemerintah. Jika peluang kelahiran bayi laki-laki itu besar, maka peluang keberhasilan kebijakan satu anak berhasil. Selain itu kebijakan satu anak di China merupakan kebijakan yang diterapkan pada masa pemerintahan Deng Xiaoping di tahun 1979 sampai pada akhirnya dihapuskan pada akhir tahun 2015. Keputusan penghapusan kebijakan ini tentu saja menjadi hal yang sangat menarik karena kebijakan ini telah dilaksanakan selama lebih dari tiga dekade dan telah berhasil mendorong pertumbuhan ekonomi dan peningkatan standar hidup masyarakat China. Setelah lebih dari tiga dekade diterapkan, berbagai dampak sosial dan ekonomi dirasakan oleh China sebagai akibat dari kebijakan satu anak. Rendahnya tingkat kesuburan di China, timpangnya rasio jenis kelamin, dan ageing population menjadi masalah baru yang dihadapi China karena pemberlakuan kebijakan ini. Dengan mempertimbangkan dampak-dampak tersebut, maka pemerintah China secara resmi menghapus kebijakan satu anak dan menerapkan kebijakan baru yang memperbolehkan setiap pasangan di China untuk memiliki dua anak.
\end{abstract}

Kata Kunci: China; distribusi geometri; distribusi binomial; Kebijakan Satu Anak; 


\section{PENDAHULUAN}

Pertumbuhan penduduk di dunia selalu menunjukkan angka yang positif. Artinya, tingkat penduduk yang lahir (natalitas) lebih banyak daripada angka penduduk yang mati (mortalitas). Ini menjadi masalah disetiap Negara didunia. Berbagai cara untuk mengendalikan jumlah penduduk.

Republik Rakyat Cina merupakan sebuah negara yang berfaham komunis,terletak di Asia Timur yang beribu kota di Beijing dengan kota besar yang terkenal, Shanghai. Negara ini adalah negara dengan kapasitas penduduk terpadat di dunia. Pemerintah Cina telah menggunakan beberapa metode untuk mengendalikan pertumbuhan penduduk. Pada tahun 1979, Cina memulai "kebijakan satu anak per keluarga". Kebijakan ini menyatakan bahwa warga negara harus mendapatkan akte kelahiran sebelum kelahiran anak mereka. Warga akan ditawarkan manfaat khusus jika mereka sepakat untuk hanya memiliki satu anak. Warga negara yang memang memiliki lebih dari satu anak akan dikenakan pajak sampai 50\% dari pendapatan mereka, Pasangan yang melanggar kebijakan tersebut diharuskan membayar denda dari US\$40.000 atau dihukum kehilangan pekerjaan atau manfaat lainnya.

Negara Cina telah lama mengalami masalah pertumbuhan penduduk. Dalam usaha membatasi perkembangan populasinya, pemerintah Cina telah mengambil kebijakan yang membatasi keluarga di perkotaan menjadi 1 anak dan keluarga di pedalaman 2 anak saat yang pertama wanita tetapi unuk etnis minoritas dikecualikan. Karena lelaki dianggap lebih bernilai ekonomis di daerah pedesaan, muncullah insiden tinggi mengenai aborsi selektif jenis kelamin dan penolakan anak di daerah pedesaan buat memastikan bahwa anak kedua ialah laki-laki. Dasar ini hanyalah untuk penduduk mayoritas bangsa Han. Terdapat banyak rumah anak yatim untuk anak-anak terlantar ini, akan tetapi hanya $2 \%$ saja yang dijadikan anak angkat oleh orang lain. Yang selebihnya pula besar di rumah anak yatim itu. pemerintah Cina telah menerapkan program pengambilan anak angkat internasional, di mana sebagian besar anak yang siangkat adalah perempuan, tetapi program ini menampakkan hasil yang tidak memuaskan.

Preferensi budaya untuk anak-anak telah menyebabkan sejumlah besar insiden pembunuhan bayi perempuan. Akibatnya, pemerintah Cina telah mengambil kebijakan "daughter only household " yang memungkinkan pasangan pedesaan yang awalnya memiliki anak perempuan pertama diizinkan untuk memiliki anak kedua. Ini dikarenakan budaya di Cina jika suatu saat menikah maka istri harus ikut suami. Jika 1 anak itu 
meraka mendapat anak perempuan maka pada masa tua dikhawatirkan tidak ada yang merawat.

\section{METODE PENELITIAN}

Metode yang digunakan untuk menulis ini adalah data sekunder melalui studi literatur atau studi pustaka. Studi pustaka ini berupa buku-buku literature, media cetak, dan media elektronik (internet) yang berhubungan dengan permasalahan yang akan dibahas.

\subsection{Distribusi Geometrik}

Distribusi geometrik merupakan bentuk khusus dari distribusi binomial negatif dengan $\mathrm{n}$ percobaan dan berakhir ketika pertama kali ditemukan sukses. Pada distribusi binomial negatif dengan rumus $b^{*}(n ; k, p)=\left(\begin{array}{l}n-1 \\ k-1\end{array}\right) p^{k} q^{n-k}$ untuk $=\mathrm{k}, \mathrm{k}+1, \mathrm{k}+2, \ldots$. Jika $\mathrm{k}=1$ atau dengan kata lain, jumlah kesuksesan yang diperlukan adalah satu sebanyak n percobaan, maka distribusi binomial negatif menjadi distribusi geometric dengan definisi di bawah.

\section{Definisi:}

Bila tindakan yang bebas dan berulang-ulang dapat menghasilkan keberhasilan dengan peluang $\mathrm{p}$ dan kegagalan dengan peluang $\mathrm{q}=1-\mathrm{p}$, maka sebaran peluang bagi peubah acak $\mathrm{X}$, yaitu banyaknya ulangan sampai munculnya keberhasilan yang pertama, diberikan menurut rumus :

$$
\mathbf{g}(\mathbf{x} ; \mathbf{p})=\mathbf{p q}^{\mathbf{x}-\mathbf{1}} \quad \text { Untuk } \mathbf{x}=1,2,3, \ldots
$$

Fungsi densitas di atas dapat diperoleh dengan ilustrasi sebagai berikut.

\begin{tabular}{|l|l|l|}
\hline \multicolumn{1}{|c|}{ banyaknya berhasil } & \multicolumn{1}{|c|}{ Susunan } & \multicolumn{1}{c|}{ Peluang } \\
\hline 1 & B & $p$ \\
\hline 2 & G B & $(1-p) p$ \\
\hline 3 & G G B & $(1-p)^{2} p$ \\
\hline$\ldots \ldots$ & $\ldots$ & $\ldots$ \\
\hline$x$ & G G G ... G B & $(1-p)^{x-1} p$ \\
\hline
\end{tabular}


Keterangan:
B: berhasil
G: gagal

\subsection{Distribusi Binomial}

Distribusi Binomial adalah suatu distribusi probabilitas yang dapat digunakan bilamana suatu proses sampling dapat diasumsikan sesuai dengan proses Bernoulli. Misalnya, dalam perlemparan sekeping uang logam sebanyak 5 kali, hasil setiap ulangan mungkin muncul sisi gambar atau sisi angka. Begitu pula, bila kartu diambil berturut-turut, kita dapat memberi label "berhasil" bila kartu yang terambil adalah kartu merah atau "gagal" bila yang terambil adalah kartu hitam. Ulangan-ulangan tersebut bersifat bebas dan peluang keberhasilan setiap ulangan tetap sama,yaitu sebasar 1/2 (Ronald E. Walpole). Adapun definisi distribusi binomial di bawah :

\section{Definisi:}

Bila suatu ulangan binom mempunyai peluang peluang keberhasilan $p$ dan kegagalan dengan peluang $q=1-p$, maka sebaran peluang bagi peubah acak binomial $X$, yaitu banyaknya keberhasilan dalam $n$ ulangan yang bebas adalah :

$$
\boldsymbol{b}(\boldsymbol{y} ; \boldsymbol{n}, \boldsymbol{\theta})=\left(\begin{array}{c}
m \\
y
\end{array}\right) \boldsymbol{p}^{y} \boldsymbol{q}^{n-y} \quad \text { Untuk } y=0,1,2,3, \ldots, n
$$

Adapun Ciri-ciri Distribusi Binomial yaitu:

1. Setiap percobaan hanya memiliki dua peristiwa, seperti sukses-gagal.

2. Probabilitas satu peristiwa adalah tetap, tidak berubah untuk setiap perubahan.

3. Percobaannya bersifat independen, artinya peristiwa dari suatu percobaan tidak mempengaruhi atau dipengaruhi peristiwa dalam percobaan lainnya.

4. Jumlah atau banyaknya percobaan yang merupakan komponen percobaan binomial harus tetap.

\subsection{Analisis Regresi}

Dalam analisis regresi kita mengasumsikan bahwa $\mathrm{x}_{\mathrm{i}}$ dalam contoh acak $\left\{\left(\mathrm{x}_{\mathrm{i}}, \mathrm{y}_{\mathrm{i}}\right) ; \mathrm{i}=1,2,3, \ldots, \mathrm{n}\right\}$ bersifat tetap dan bukan merupakan nilai peubah acak. Seandainya suatu contoh lain yang berukuran $n$ diambil dengan 
menggunakan nilai-nilai $\mathrm{x}$ yang sama, kita dapat membayangkan bahwa nilainilai y akan bervariasi, berbeda dari nilai-nilai sebelumnya.

Dengan demikian nilai $\mathrm{y}_{\mathrm{i}}$ dalam pasangan $\left(\mathrm{x}_{\mathrm{i}}, \mathrm{y}_{\mathrm{i}}\right)$ merupakan nilai suatu peubah aca $\mathrm{Y}_{\mathrm{i}}$. Untuk memudahkan peubah acak $\mathrm{Y}$ padanan nilai tertentu $\mathrm{x}$ akan dilambangkan dengan $\mathrm{Y} \mid \mathrm{x}$, sedangkan nilai tengah dan ragamnya masingmasing akan dilambangkan dengan $\mu \mathrm{Y} \mid \mathrm{x}$ dan $\sigma^{2} \mathrm{Y} \mid \mathrm{x}$. Jadi jelaslah, jika $\mathrm{x}=\mathrm{x}_{\mathrm{i}}$, maka lambing $\mathrm{Y} \mid \mathrm{x}_{\mathrm{i}}$ menyatakan peubah acak $Y_{\bar{i}}$ dengan nilai tengah $\mu Y \mid x_{\bar{i}}$ dan ragam $\sigma^{2} Y \mid x_{i}$. Kita menaruh perhatian pada sebaran segugus peubah acak $\left\{\mathrm{Y}_{\mathrm{i}} ; \mathrm{i}=1,2,3, \ldots, \mathrm{n}\right\}$, yang semuanya diasumsikan bebas. Untuk tujuan pembuatan selang kepercayaan dan pengujian hipotesis, kita juga akan menyaratkan bahwa $\mathrm{Y}_{1_{0}} \mathrm{Y}_{2}, \ldots, \mathrm{Y}_{\mathrm{n}}$ masing-masing menyebar normal.

Kurva yang menghubungkan nilai tengah setiap sebaran itu disebut kurva regresi. Bila semua nilai tengah $\mu \mathrm{Y} \mid \mathrm{x}$ jatuh tepat pada suatu garis lurus maka regresinya linier dan dapat dinyatakan menurut persamaan

$$
\mu \mathrm{Y} \mid \mathrm{x}=\alpha+\beta \mathrm{x}
$$

Parameter $\alpha$ dan $\beta$ disebut koefisien regresi. Dengan melambangkan nilai dugaannya masing-masing dengan a dan $\mathrm{b}$, maka kita menduga $\mu \mathrm{Y} \mid \mathrm{x}$ dengan y dari garis regresi yaitu :

$$
\hat{y}=a+b x
$$

\section{HASIL DAN PEMBAHASAN}

\subsection{MODEL MATEMATIKA}

Terus meningkatnya populasi penduduk yang sangat cepat, mendorong pemerintah dari berbagai negara untuk membuat kebijakan agar tingkat pertumbuhan penduduk dapat dikendalikan. Salah satu contoh Negara yang membuat kebijakan tersebut adalah China. Di China, pemerintahnya menetapkan satu orang anak untuk satu keluarga. Hal ini dilakukan dalam tujuan untuk mengurangi jumlah penduduk di China. Tentu saja kebijakan ini akan berhasil jika sambutan masyarakat cukup baik, yaitu menerima dan menerapkan aturan ini. 
Terdapat kendala dalam penerapan kebijakan satu orang anak untuk satu keluarga di China. Salah satunya adalah faktor budaya, yaitu satu keluarga harus memiliki seorang anak laki-laki. Dalam hal ini pemerintah jelas mengalami kendala, apabila suatu keluarga anak pertama bukan laki-laki, maka keluarga tersebut akan berusaha untuk mendapatkan anak lagi dengan harapan mendapatkan anak laki-laki. Jadi pada kenyataanya dalam suatu keluarga bisa saja dikarunia seorang anak laki-laki setelah anak kedua, ketiga dan seterusnya.

Pandang sebuah keluarga yang memiliki anak, misalkan X adalah Variabel Random yang menyatakan banyaknya anak hingga memperoleh anak laki-laki dan peluang untuk memperoleh anak laki-laki pada setiap kehamilan diasumsikan sama yaitu p. Misalkan dibutuhkan $\mathrm{x}$ kelahiran hingga memperoleh anak laki-laki. Tentunya dengan asumsi bahwa setelah lahir anak laki-laki maka tidak ada lagi anak berikutnya yang akan lahir. Jadi variable random $\mathrm{x}$ yang diamati ini berdistribusi geometri, dengan parameter $\mathrm{p}$ yang memiliki fungsi densitas peluang sebagai berikut.

$$
g(x ; p)=(1-p)^{x-1} p \quad x=1,2,3 \ldots
$$

Walaupun aturan yang diterapkan adalah satu anak untuk satu keluarga, tetapi masih dimungkinkan untuk mempunyai dua orang anak asalkan anak yang pertama lahir adalah anak perempuan. Sehingga Peluang bahwa sebuah keluarga akan mengikuti aturan pemerintah sama dengan peluang sebuah keluarga maksimal memiliki 2 orang anak yang dapat dihitung sebagai berikut.

$$
\theta=P(X \leq 2)=g(1 ; p)+g(2 ; p)=p(2-p)
$$

Sekarang perhatikan Variabel random Y yang menyatakan banyaknya keluarga yang patuh terhadap peraturan pemerintah, yaitu mempunyai maksimal 2 orang anak. Jika terdapat sebanyak n keluarga dan dianggap setiap keluarga mempunyai peluang yang sama untuk mematuhi peraturan, yaitu $\theta$, maka variabel random $\mathrm{Y}$ berdistribusi binomial dengan parameter $\mathrm{n}$ dan $\theta$ yang memiliki fungsi densitas sebagai berikut.

$$
b(y ; n, \theta)=c_{y}^{n} \theta^{y}(1-\theta)^{n-y}
$$

$y=0,1,2, \ldots n$, dengan fungsi distribusi kumulatif sebagai berikut. 
$B(y ; n, \theta)=\sum_{i=1}^{y} C_{i}^{n} \theta^{i}(1-\theta)^{n-i}$

\subsection{SIMULASI NUMERIK}

Pada bagian ini akan dilakukan simulasi numerik pada model matematika di atas untuk nilai p yang dibangkitkan secara random dengan menggunakan Ms Excel. Hasilnya diperolah sebanyak 100 data nilai p, yang menyatakan peluang memperoleh satu anak laki-laki dalam sebuah keluarga. Kemudian dari nilai p diperoleh nilai $\theta$ dan juga $B(y ; n, \theta)$.

Program pemerintah dikatakan berhasil jika jumlah penduduk yang mengikuti peraturan pemerintah semakin banyak. Hal ini dapat dijadikan sebagai indikator untuk mengukur tingkat keberhasilan kebijakan pemerintah. Dalam simulasi ini, digunakan angka $75 \%, 80 \%$, dan $90 \%$ dari $\mathrm{n}$ pasangan sebagai batasan untuk mengukur keberhasilan kebijakan pemerintah. Hasil simulasi lengkap diperlihatkan oleh table dibawah ini.

Tabel. Simulasi Numerik Nilai p

\begin{tabular}{|r|r|r|r|r|r|}
\hline No & \multicolumn{1}{l|l}{$\theta$} & \multicolumn{1}{l|}{$b(y>75 ; 100, \theta)$} & $b(y>80 ; 100, \theta)$ & $b(y>90 ; 100, \theta)$ \\
\hline 1 & 0.773 & 0.948471 & 1 & 1 & 0.408890784 \\
\hline 2 & 0.83 & 0.9711 & 1 & 1 & 0.836054205 \\
\hline 3 & 0.384 & 0.620544 & 0.002196 & $3.45 \mathrm{E}-05$ & $5.55112 \mathrm{E}-16$ \\
\hline 4 & 0.873 & 0.983871 & 1 & 1 & 0.976684274 \\
\hline 5 & 0.291 & 0.497319 & $6.81 \mathrm{E}-08$ & $9.65 \mathrm{E}-11$ & $7.77156 \mathrm{E}-15$ \\
\hline 6 & 0.788 & 0.955056 & 1 & 1 & 0.531014843 \\
\hline 7 & 0.729 & 0.926559 & 1 & 0.999965 & 0.134009644 \\
\hline 8 & 0.446 & 0.693084 & 0.08761 & 0.005951 & $1.98755 \mathrm{E}-11$ \\
\hline 9 & 0.808 & 0.963136 & 1 & 1 & 0.691014759 \\
\hline 10 & 0.209 & 0.374319 & $4.77 \mathrm{E}-15$ & $2.22 \mathrm{E}-16$ & $2.22045 \mathrm{E}-16$ \\
\hline 11 & 0.88 & 0.9856 & 1 & 1 & 0.984890212 \\
\hline 12 & 0.448 & 0.695296 & 0.095359 & 0.006777 & $2.62446 \mathrm{E}-11$ \\
\hline 13 & 0.487 & 0.736831 & 0.345596 & 0.057283 & $3.91912 \mathrm{E}-09$ \\
\hline 14 & 0.696 & 0.907584 & 0.999997 & 0.999242 & 0.040251999 \\
\hline 15 & 0.416 & 0.658944 & 0.01924 & 0.000653 & $2.37144 \mathrm{E}-13$ \\
\hline 16 & 0.371 & 0.604359 & 0.000759 & $8.66 \mathrm{E}-06$ & $4.44089 \mathrm{E}-15$ \\
\hline 17 & 0.99 & 0.9999 & 1 & 1 & 1 \\
\hline 18 & 0.872 & 0.983616 & 1 & 1 & 0.97527132 \\
\hline 19 & 0.26 & 0.4524 & $3.73 \mathrm{E}-10$ & $2.16 \mathrm{E}-13$ & $3.10862 \mathrm{E}-15$ \\
\hline & & & & & \\
\hline
\end{tabular}




\begin{tabular}{|c|c|c|c|c|c|}
\hline 20 & 0.782 & 0.952476 & 1 & 1 & 0.481593373 \\
\hline 21 & 0.674 & 0.893724 & 0.999963 & 0.995999 & 0.01502471 \\
\hline 22 & 0.434 & 0.679644 & 0.050536 & 0.002609 & $3.57825 \mathrm{E}-12$ \\
\hline 23 & 0.939 & 0.996279 & 1 & 1 & 0.999959965 \\
\hline 24 & 0.908 & 0.991536 & 1 & 1 & 0.998319318 \\
\hline 25 & 0.259 & 0.450919 & $3.09 \mathrm{E}-10$ & $1.86 \mathrm{E}-13$ & $9.76996 \mathrm{E}-15$ \\
\hline 26 & 0.862 & 0.980956 & 1 & 1 & 0.957202261 \\
\hline 27 & 0.296 & 0.504384 & $1.43 \mathrm{E}-07$ & $2.33 \mathrm{E}-10$ & $1.11022 \mathrm{E}-15$ \\
\hline 28 & 0.985 & 0.999775 & 1 & 1 & 1 \\
\hline 29 & 0.722 & 0.922716 & 1 & 0.999928 & 0.10667471 \\
\hline 30 & 0.835 & 0.972775 & 1 & 1 & 0.862217616 \\
\hline 31 & 0.22 & 0.3916 & $6.84 \mathrm{E}-14$ & $6.44 \mathrm{E}-15$ & 6.43929E-15 \\
\hline 32 & 0.286 & 0.490204 & $3.15 \mathrm{E}-08$ & $3.89 \mathrm{E}-11$ & $2.44249 \mathrm{E}-15$ \\
\hline 33 & 0.439 & 0.685279 & 0.06412 & 0.003714 & 7.37843E-12 \\
\hline 34 & 0.293 & 0.500151 & $9.2 \mathrm{E}-08$ & $1.38 \mathrm{E}-10$ & 4.44089E-15 \\
\hline 35 & 0.594 & 0.835164 & 0.980864 & 0.794909 & 0.000111385 \\
\hline 36 & 0.818 & 0.966876 & 1 & 1 & 0.762481124 \\
\hline 37 & 0.829 & 0.970759 & 1 & 1 & 0.830494116 \\
\hline 38 & 0.383 & 0.619311 & 0.002032 & $3.12 \mathrm{E}-05$ & $5.55112 \mathrm{E}-16$ \\
\hline 39 & 0.851 & 0.977799 & 1 & 1 & 0.927514536 \\
\hline 40 & 0.475 & 0.724375 & 0.24948 & 0.032128 & $9.10885 \mathrm{E}-10$ \\
\hline 41 & 0.815 & 0.965775 & 1 & 1 & 0.741906053 \\
\hline 42 & 0.927 & 0.994671 & 1 & 1 & 0.999787452 \\
\hline 43 & 0.353 & 0.581391 & 0.000144 & $1.05 \mathrm{E}-06$ & 3.21965E-15 \\
\hline 44 & 0.484 & 0.733744 & 0.3203 & 0.049884 & $2.7389 \mathrm{E}-09$ \\
\hline 45 & 0.901 & 0.990199 & 1 & 1 & 0.996847385 \\
\hline 46 & 0.386 & 0.623004 & 0.002561 & 4.23E-05 & $6.66134 \mathrm{E}-16$ \\
\hline 47 & 0.244 & 0.428464 & $1.62 \mathrm{E}-11$ & $5.55 \mathrm{E}-16$ & $5.55112 \mathrm{E}-15$ \\
\hline 48 & 0.341 & 0.565719 & 4.19E-05 & $2.25 \mathrm{E}-07$ & $2.66454 \mathrm{E}-15$ \\
\hline 49 & 0.854 & 0.978684 & 1 & 1 & 0.936751206 \\
\hline 50 & 0.524 & 0.773424 & 0.676309 & 0.228247 & $2.3202 \mathrm{E}-07$ \\
\hline 51 & 0.508 & 0.757936 & 0.535285 & 0.134791 & $4.28201 \mathrm{E}-08$ \\
\hline 52 & 0.616 & 0.852544 & 0.995125 & 0.906537 & 0.000532192 \\
\hline 53 & 0.703 & 0.911791 & 0.999999 & 0.99958 & 0.053385542 \\
\hline 54 & 0.246 & 0.431484 & $2.44 \mathrm{E}-11$ & $1.07 \mathrm{E}-14$ & $1.22125 \mathrm{E}-15$ \\
\hline 55 & 0.892 & 0.988336 & 1 & 1 & 0.993489048 \\
\hline 56 & 0.645 & 0.873975 & 0.99946 & 0.976166 & 0.003245965 \\
\hline 57 & 0.435 & 0.680775 & 0.053055 & 0.002803 & 4.14202E-12 \\
\hline 58 & 0.69 & 0.9039 & 0.999993 & 0.998773 & 0.031225243 \\
\hline 59 & 0.847 & 0.976591 & 1 & 1 & 0.913772427 \\
\hline 60 & 0.858 & 0.979836 & 1 & 1 & 0.947708085 \\
\hline 61 & 0.936 & 0.995904 & 1 & 1 & 0.999937177 \\
\hline 62 & 0.95 & 0.9975 & 1 & 1 & 0.999993966 \\
\hline 63 & 0.487 & 0.736831 & 0.345596 & 0.057283 & 3.91912E-09 \\
\hline
\end{tabular}




\begin{tabular}{|c|c|c|c|c|c|}
\hline 64 & 0.795 & 0.957975 & 1 & 1 & 0.588515422 \\
\hline 65 & 0.755 & 0.939975 & 1 & 0.999998 & 0.276433871 \\
\hline 66 & 0.881 & 0.985839 & 1 & 1 & 0.985844429 \\
\hline 67 & 0.482 & 0.731676 & 0.303868 & 0.045386 & 2.15179E-09 \\
\hline 68 & 0.846 & 0.976284 & 1 & 1 & 0.91007469 \\
\hline 69 & 0.831 & 0.971439 & 1 & 1 & 0.841505944 \\
\hline 70 & 0.609 & 0.847119 & 0.992261 & 0.877278 & 0.000329557 \\
\hline 71 & 0.235 & 0.414775 & $2.38 \mathrm{E}-12$ & $2.44 \mathrm{E}-15$ & $2.88658 \mathrm{E}-15$ \\
\hline 72 & 0.674 & 0.893724 & 0.999963 & 0.995999 & 0.01502471 \\
\hline 73 & 0.323 & 0.541671 & 5.33E-06 & 1.79E-08 & $5.55112 \mathrm{E}-15$ \\
\hline 74 & 0.744 & 0.934464 & 1 & 0.999993 & 0.208308763 \\
\hline 75 & 0.489 & 0.738879 & 0.362847 & 0.062672 & 4.9648E-09 \\
\hline 76 & 0.868 & 0.982576 & 1 & 1 & 0.968941299 \\
\hline 77 & 0.929 & 0.994959 & 1 & 1 & 0.999835322 \\
\hline 78 & 0.309 & 0.522519 & 8.87E-07 & 2.05E-09 & $2.66454 \mathrm{E}-15$ \\
\hline 79 & 0.834 & 0.972444 & 1 & 1 & 0.857204903 \\
\hline 80 & 0.556 & 0.802864 & 0.883764 & 0.488782 & 4.94207E-06 \\
\hline 81 & 0.877 & 0.984871 & 1 & 1 & 0.981715416 \\
\hline 82 & 0.765 & 0.944775 & 1 & 0.999999 & 0.34730965 \\
\hline 83 & 0.908 & 0.991536 & 1 & 1 & 0.998319318 \\
\hline 84 & 0.584 & 0.826944 & 0.96713 & 0.725411 & 5.16835E-05 \\
\hline 85 & 0.782 & 0.952476 & 1 & 1 & 0.481593373 \\
\hline 86 & 0.822 & 0.968316 & 1 & 1 & 0.788618579 \\
\hline 87 & 0.864 & 0.981504 & 1 & 1 & 0.961434494 \\
\hline 88 & 0.33 & 0.5511 & $1.23 \mathrm{E}-05$ & 4.94E-08 & $2.77556 \mathrm{E}-15$ \\
\hline 89 & 0.477 & 0.726471 & 0.264489 & 0.035544 & 1.16732E-09 \\
\hline 90 & 0.705 & 0.912975 & 0.999999 & 0.999647 & 0.057713682 \\
\hline 91 & 0.98 & 0.9996 & 1 & 1 & 0.999999999 \\
\hline 92 & 0.238 & 0.419356 & $4.58 \mathrm{E}-12$ & $5.33 \mathrm{E}-15$ & $3.9968 \mathrm{E}-15$ \\
\hline 93 & 0.806 & 0.962364 & 1 & 1 & 0.675824362 \\
\hline 94 & 0.588 & 0.830256 & 0.97337 & 0.754516 & 7.05719E-05 \\
\hline 95 & 0.408 & 0.649536 & 0.011831 & 0.000332 & $6.25056 \mathrm{E}-14$ \\
\hline 96 & 0.465 & 0.713775 & 0.181554 & 0.018833 & $2.55789 \mathrm{E}-10$ \\
\hline 97 & 0.602 & 0.841596 & 0.988023 & 0.842218 & 0.000200622 \\
\hline 98 & 0.43 & 0.6751 & 0.041388 & 0.001948 & $1.98663 \mathrm{E}-12$ \\
\hline 99 & 0.926 & 0.994524 & 1 & 1 & 0.999759268 \\
\hline 100 & 0.991 & 0.999919 & 1 & 1 & 1 \\
\hline
\end{tabular}

Dari table di atas untuk nilai n dan p yang sama dapat dilihat bahwa Jika $\mathrm{y}_{1}<\mathrm{y}_{2} \leq \mathrm{n}$ maka $\mathrm{b}\left(\mathrm{y}_{2} ; \mathrm{n}, \theta\right)<b\left(\mathrm{y}_{1} ; \mathrm{n}, \theta\right)$. Hal ini menunjukkan bahwa semakin besar persentase keberhasilan yang ingin dicapai, maka nilai peluangnya akan semakin kecil. Selain itu, dari tabel di atas dapat dilihat besarnya nilai peluang lahir 
anak laki-laki dalam sebuah keluarga, akan memberikan pengaruh terhadap peluang keberhasilan kebijakan pemerintah. Selanjutnya, untuk mengetahui hubungan atau pengaruh tersebut dibuat persamaan regresi linier antara $\mathrm{p}$ sebagai variable bebas dengan $1-\mathrm{B}(\mathrm{y} ; \mathrm{n}, \theta)$ sebagai variable tak bebasnya.

Tabel. Persamaan Regresi

\begin{tabular}{|l|r|r|r|}
\hline & \multicolumn{3}{|c|}{ Variabel Tak Bebas } \\
\hline & $b(y>75 ; 100, \theta)$ & $b(y>80 ; 100, \theta)$ & $b(y>90 ; 100, \theta)$ \\
\hline Slope & 1.743643 & 1.846596 & 1.619685 \\
\hline Intercep & -0.46422 & -0.57683 & -0.65229 \\
\hline
\end{tabular}

Dari table di atas dapat dilihat bahwa terdapat hubungan yang positif antara $\mathrm{p}$ dan $b(y ; n, \theta)$. Artinya semakin besar peluang lahirnya anak laki-laki dalam sebuah keluarga maka peluang keberhasilan kebijakan pemerintah juga akan semakin besar.

\section{KESIMPULAN}

Berdasarkan pembahasan masalah di atas, dapat disumpulkan hal-hal sebagai berikut.

1. Distribusi peluang yang sesuai dengan pertumbuhan penduduk jika suatu keluarga harus mendapatkan anak laki-laki adalah distribusi geometri. Untuk n keluarga digunakan distribusi binomial yang mengukur tingkat keberhasilan pemerintah. Jika peluang kelahiran bayi laki-laki itu besar, maka peluang keberhasilan kebijakan satu anak berhasil.

2. Kebijakan satu anak di Cina sangatlah relevan dengan keadaan Cina sejak tahun 1970-an. Walaupun dinilai sangat kejam, dimana kebijakan ini diikuti dengan banyaknya janin yang mati, Sehingga pada akhirnya 2015 dihapuskan kebijakan tersebut.

\section{DAFTAR PUSTAKA}

1. Bluman, A.G., (2012), Elementary Statistics: A Step By Step Approach, Eighth Edition, New York: McGraw-Hill. 
2. Walpole, R.E., Myers, R.H., Myers, S.L., and Ye, K., (2012), Probability and Statistics for Engineers and Scientists, Ninth Edition, Boston: Pearson Education.

3. Lefebvre, M., (2006), Applied Probability and Statistics, New York: Springer.

Settles, B. H. dkk. (2013). the one child policy and its impact on Chinese families.

Dalam Chan Kwok-bun (Ed.), International Handbook of Chinese Families (627-646). Newyork: Springer Science+Business Media. 